\title{
Analisis Kesejahteraan Ekonomi Keluarga Pelaku Usaha Mikro Kota Bandung di Masa Pandemi
}

\author{
Nelies Nur Sholihah", Westi Riani \\ Prodi Ilmu Ekonomi dan Bisnis, Fakultas Ekonomi dan Bisnis, Universitas \\ Islam Bandung, Indonesia. \\ *neliesnursholihah@gmail.com, westiriani@unisba.ac.id
}

\begin{abstract}
Pandemic covid - 19 brings a very painful impact for almost all countries, including Indonesia. Many people are badly affected by the pandemic. A lot of changes is faced by families in the education sector, economy, health and so on that affects the lives of all family members. The purpose of this study is to find out the condition of economic resilience of the family of micro-businesses in the city of Bandung This study uses qualitative descriptive analysis methods using phenomenological studies and in analysis using the range score calculation formula published by the Central Bureau of Statistics (BPS). The data used in this study is primary data obtained from the results of the dissemination of questionnaires conducted to micro-businesses in The City of Bandung. The results of the research showed that the economic welfare condition of the family of micro-businesses in The City of Bandung is fairly prosperous but this is contrary to the existing phenomenon so it needs in-depth analysis to know this can happen.
\end{abstract}

Keywords: Business actors, Family economic welfare.

Abstrak. Pandemi covid - 19 membawa dampak yang sangat menyakitkan bagi hampir seluruh negara, termasuk Indonesia. Banyak masyarakat yang terkena imbas buruk dari adanya pandemi. Perubahan demi perubahan dihadapi oleh keluarga pada sektor pendidikan, ekonomi, kesehatan dan sebagainya sehingga memengaruhi kehidupan seluruh anggota keluarga. Tujuan dari penelitian ini adalah untuk mengetahui kondisi ketahanan ekonomi keluarga pelaku usaha mikro di Kota Bandung Penelitian ini menggunakan metode analisis deskriptif kualitatif dengan menggunakan studi fenomenologi dan di analisis menggunakan rumus perhitungan Range Score yang di publikasikan oleh Badan Pusat Statistik (BPS). Data yang digunakan dalam penelitian ini adalah data primer yang diperoleh dari hasil penyebaran kuesioner yang dilakukan kepada para pelaku usaha mikro di Kota Bandung. Hasil dari penelitian menunjukkan bahwa kondisi kesejahteraan ekonomi keluarga pelaku usaha mikro di Kota Bandung terbilang sejahtera namun hal ini bertolak belakang dengan fenomena yang ada sehingga perlu analisis mendalam untuk mengetahui hal ini bisa terjadi.

Kata Kunci: Pelaku usaha, Kesejahteraan ekonomi keluarga. 


\section{A. Pendahuluan}

Pada Maret 2019 Organisasi Kesehatan Internasional (WHO) menetapkan COVID - 19 menjadi pandemi. Hal tersebut menyebabkan Negara - Negara mendadak mengambil kebijakan lockdown sebagai upaya yang dirasa paling efektif untuk dilakukan sesegera mungkin guna meminimalisir penyebaran virus, begitupun Indonesia yang mengambil langkah lockdown berbentuk Pembatasan Sosial Berskala Besar (PSBB) yang bertujuan memutus rantai penyebaran virus. Langkah ini dianggap efektif untuk mencegah penyebaran virus namun di sisi lain menimbulkan eksternalitas negatif yaitu terhentinya kegiatan ekonomi nasional serta beberapa dampak lainnya (Nurhayati \& Aji, 2020).

Salah satunya adalah dampak terhadap kesejahteraan keluarga yang cukup menghawatirkan. Menurut Ketua Departemen Ilmu Keluarga dan Konsumen (IKK), Fakultas Ekologi Manusia IPB Dr. Tin Herawati, pandemi telah memengaruhi sistem lingkungan terbesar (makrosistem) yang tentunya juga berdampak pada lingkungan terkecil (mikrosistem) yaitu keluarga. Perubahan demi perubahan dihadapi oleh keluarga pada sektor pendidikan, ekonomi, kesehatan dan sebagainya sehingga memengaruhi kehidupan seluruh anggota keluarga. Hal inilah yang memicu pemerintah untuk mengeluarkan kebijakan-kebijakan untuk melindungi anggota keluarga dari penularan COVID-19 seperti penutupan sekolah, physical distancing, Pembatasan Sosial Berskala Besar (PSBB) dan Work from Home (WFH). Adanya kebijakankebijakan tersebut, isu keluarga muncul lagi, terutama isu tidak stabilnya pekerjaan yang dimiliki keluarga. Pekerjaan yang tidak stabil inilah yang memicu munculnya berbagai permasalahan lainnya dalam keluarga. Keluarga merupakan salah satu agen sosialisasi yang paling penting dalam mengajarkan aggotanya mengenai aturan-aturan yang diharapkan oleh masyarakat. Kemampuan keluarga mengendalikan individu secara terus menerus, merupakan kekuatan sosial yang tidak dapat ditemukan pada lembaga lainnya (Herawati, 2020).

Pendapatan menjadi unsur penting dalam membangun ekonomi keluarga (Shahreza \& Lindiawatie, 2020). Penurunan pendapatan ini berdampak pada ketahanan ekonomi dan kesejahteraan keluarga karena keluarga kehilangan sebagian pendapatan untuk menunjang kehidupan. Menurut survey Nasional Saiful Mujani Research Center (SMRC) ketahanan ekonomi keluarga kian memburuk sejak pandemi.

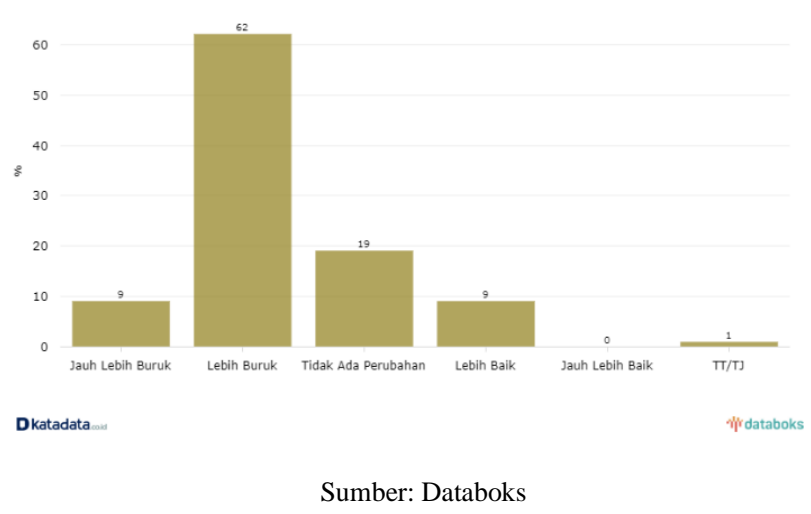

Gambar 1. Perbandingan Keadaan Ekonomi Rumah Tangga Sekarang dan Sebelum Pandemi

Hasil survei Saiful Mujani Research Center (SMRC) secara dominan menunjukkan bahwa kondisi ekonomi rumah tangga saat ini lebih buruk dari sebelum adanya pandemi. Sebanyak $62 \%$ menjawab lebih buruk dan $9 \%$ jauh lebih buruk. Hanya $9 \%$ yang menyatakan merasa lebih baik. Sementara itu, terdapat $19 \%$ responden yang menilai tidak ada perubahan. Survei ini dilakukan pada 18-20 Juni 2020. Sampel dipilih secara acak dari populasi pemilih yang berusia 17 tahun ke atas/sudah menikah sebanyak 1.978 responden dengan tingkat kepercayaan $95 \%$. Survei tersebut dilakukan melalui wawancara tatap muka via daring (Jayani, 2020). 
Penelitian tersebut didukung oleh data survei yang dilakukan oleh Badan Pusat Statistik (BPS) berikut

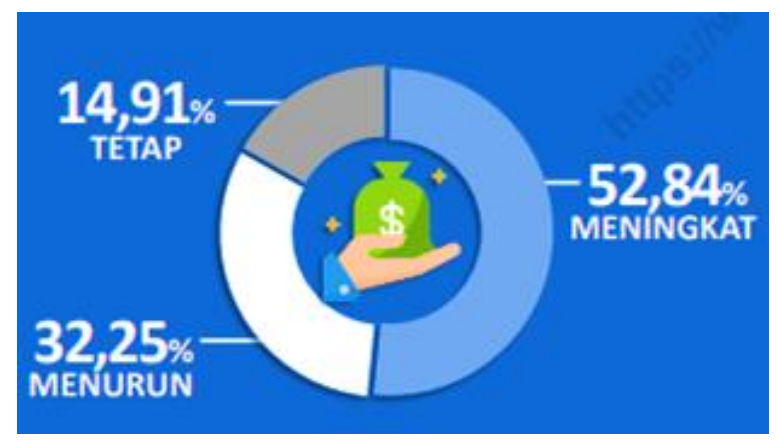

Sumber: BPS

Gambar 2. Perubahan Pengeluaran Masyarakat di Masa Pandemi

Survei menunjukkan bahwa dari 90.967 responden, hampir 53\% mengaku mengalami peningkatan pengeluaran dibandingkan awal pandemi dan PSBB (April s.d Juni 2020) sehingga pendapatan yang cenderung menurun namun pengeluaran mengalami peningkatan menjadi gap masalah yang harus dipecahkan oleh individu (BPS, 2020).

Selain pendapatan, indikator kesejahteraan keluarga lain yang mengalami masalah ialah pendidikan. Dilansir dari laman dikti, Direktur Jenderal Pendidikan Tinggi Kemendikbud, Nizam, pada acara Medan International Conference on Energy and Sustainability, Selasa (27/10) menyatakan bahwa pembelajaran daring (dalam jaringan) menjadi tantangan bagi dunia pendidikan dengan situasi Indonesia yang memiliki ribuan pulau. Permasalahan yang dihadapi ialah bagaimana teknologi dapat digunakan, bagaimana penyediaan akses internet pada daerahdaerah terpencil dimana barang elektronik tanpa akses internet pun masih menjadi suatu kemewahan, ini merupakan tantangan bagi semua pihak, saat ini seluruh elemen yang terlibat harus bekerja keras bersama bagaimana membawa teknologi serta menjawab permasalahan nyata yang terjadi pada mahasiswa dan pelajar yang kurang beruntung dalam hal ekonomi maupun teknologi yang berada di daerah-daerah terpencil dengan tujuan pemerataan pendidikan (Hendayana, 2020).

Selain Pendidikan, kesehatan pun jelas mengalami permasalahan. Dilansir dari laman CNN Indonesia, berbagai masalah kesehatan muncul ke permukaan di tahun 2020 ini. Jelas, yang terbesar adalah pandemi Covid-19, yang mengancam miliaran penduduk bumi. Sejak ditemukan pada akhir 2019 lalu, virus corona membuat kalut banyak orang. Selain itu juga mengakibatkan efek domino yang menyebar ke mana-mana, termasuk memicu masalah kesehatan lainnya. Diantaranya adalah terhambatnya imunisasi anak karena rasa takut orang tua akan penularan virus corona membuat pelaksanaan imunisasi rutin terhambat. Pada Mei 2020, Organisasi Kesehatan Dunia (WHO) menyebut, program imunisasi di 68 negara harus terhenti akibat pandemi. Sebagai akibatnya, 80 juta bayi yang tinggal di negara-negara tersebut terancam penyakit menular lain seperti campak dan polio. Cakupan imunisasi dasar pada April 2020 menurut 4,7 persen dibandingkan periode yang sama pada tahun lalu. Penurunan layanan program imunisasi terjadi di Puskesmas, Posyandu, dan fasilitas kesehatan lainnya. Lalu ada Ancaman kesehatan mental Pada Oktober lalu, WHO merilis hasil survei yang menyimpulkan bahwa pandemi telah memberikan dampaknya terhadap kesehatan mental. Sebanyak 83 persen dari 130 negara yang disurvei bahkan telah memasukkan kesehatan mental dalam rencana tanggapan pandeminya. Namun, hanya 17 persen yang benar-benar menyiapkan dana yang dibutuhkan (CNNIndonesia, 2020).

Selain survei yang dilakukan oleh SMRC, survei yang dilakukan oleh Lembaga Ilmu Pengetahuan Indonesia (LIPI) menunjukkan bahwa dampak pandemi terhadap kemampuan pengelolaan ekonomi rumah tangga ialah sebanyak 87,3 persen Rumah Tangga Usaha dan 64,8 persen Rumah Tangga Pekerja merasa mengalami kesulitan keuangan. Berdasarkan survei Rumah Tangga yang mengalami kesulitan keuangan, Rumah Tangga Pekerja lebih merasa berat 
untuk membiayai konsumsi kebutuhan pangan yaitu sebesar 52,9 persen. Adapun Rumah Tangga Usaha relatif lebih rendah yaitu sebesar 37,8 persen. Fenomena tersebut mengindikasikan bahwa secara Nasional, keluarga yang melakukan kegiatan usaha relatif lebih tahan terhadap krisis (LIPI, 2020).

Dalam penelitian LIPI disebutkan bahwa rumah tangga atau keluarga yang tidak melakukan kegiatan usaha lebih merasa berat untuk memenuhi kebutuhan primer, sementara rumah tangga atau keluarga yang melakukan kegiatan usaha relatif lebih ringan. Pelaku usaha dalam situasi pandemi memiliki tingkat ketahanan yang relatif lebih baik (Alimoeso, 2020).

Di Kota Bandung, pandemi Covid-19 melumpuhkan sekitar 6000 pelaku usaha mikro kecil menengah (UMKM) (Rachmawati, 2020). Yang dimana Kota Bandung merupakan Kota dengan Kendati demikian, masyarakat tetap berupaya untuk menjaga kestabilan ekonomi keluarga dengan cara melakukan kegiatan usaha, hal ini dikarenakan masyarakat berupaya mencari peluang dengan memanfaatkan serta mengisi waktu luang walau hanya skala mikro atau kerap disebut dengan small business (Wakhidatul, 2020).

Berdasarkan latar belakang di atas, penelitian ini dimaksudkan untuk mengetahui kesejahteraan keluarga pelaku usaha mikro sehingga penelitian ini mengangkat judul "Analisis Kesejahteraan Ekonomi Keluarga Pelaku Usaha Mikro Kota Bandung di Masa Pandemi ”.

\section{B. Metodelogi}

Penelitian ini merupakan penelitian kualitatif dengan menggunakan pendekatan studi fenomenologi. Penelitian kualitatif adalah metode penelitian yang berlandaskan pada filsafat post positivisme digunakan untuk meneliti pada kondisi obyek yang alamiah dimana peneliti sebagai instrumen kunci pengambilan sampel sumber data dilakukan secara purposive. Analisis data bersifat induktif/kualitatif, dan hasil penelitian kualitatif lebih menekankan makna daripada generalisasi (Sugiyono, Metode Penelitian Bisnis, 2008). Studi fenomenologi menurut Husserl ialah studi tentang bagaimana orang mendeskrispikan sesuatu dan mengalaminya melalui indra mereka sendiri. Dengan kata lain, fenomenologi Husserl merupakan sebuah upaya memahami kesadaran sebagaimana dialami dari sudut pandang orang yang mengalami sendiri. Studi fenomenologi dapat digambarkan sebagai penerapan metode kualitatif untuk mengeksplorasi dan menemukan makna umum dari suatu konsep atau fenomena yang merupakan pengalaman hidup sekelompok individu (Abdillah, 2021).

\section{Rancangan Populasi dan Sampel Penelitian}

Menurut Sugiyono (2018) Populasi adalah wilayah generalisasi yang terdiri atas objek/ subyek yang mempunyai kualitas dan karakteristik tertentu yang ditetapkan oleh peneliti untuk dipelajari dan kemudian ditarik kesimpulannya. Sementara sampel adalah bagian dari jumlah jumlah dan karakteristik yang dimiliki oleh populasi tersebut (Sugiyono, Metode Penelitian Bisnis, 2008).

Populasi dalam penelitian ini adalah seluruh pelaku usaha mikro di Kota Bandung, untuk jumlah populasi diperoleh dari Kementerian Koperasi dan UMKM yaitu sebanyak 334.781 usaha namun peneliti membatasi hanya pada skala usaha mikro. Pengambilan sampel dalam penelitian ini menggunakan purposive sampling dan dihitung dengan menggunakan rumus slovin. Teknik Purposive Sampling merupakan salah satu teknik pengambilan sampel dengan memilih sampel berdasarkan penelitian terhadap beberapa karakteristik anggota sampel yang disesuaikan dengan maksud penelitian dengan pertimbangan tertentu misalnya orang atau objek tersebut dianggap paling tahu tentang apa yang kita harapkan atau mungkin dia sebagai penguasa sehingga akan memudahkan peneliti menjelajahi objek/ situasi sosial yang diteliti (Kuncoro, 2009).

Teknik pengambilan sampel dihitung menggunakan rumus slovin dengan tingkat error sebesar 10\% sehingga menghasilkan jumlah minimum responden yang dianggap mewakili. Dari formula tersebut dapat dinyatakan dengan standar eror yang diharapkan sebesar $10 \%$ maka sampel yang dianggap mewakili populasi ialah 99,99 atau 100 responden (angka dibukatkan). 


\section{Hasil dan Pembahasan}

Menurut hasil analisis tingkat kesejahteraan rumah tangga berdasarkan indikator kesejahteraan Badan Pusat Statistik (2007) hasil modifikasi menunjukkan bahwa rumah tangga pelaku usaha mikro Kota Bandung termasuk ke dalam kategori sejahtera atau baik. Karena memiliki skor 14,34 yang termasuk dalam kategori sejahtera. Lebih spesifiknya, 58 responden terkategori sejahtera. Responden yang termasuk dalam kategori sejahtera ialah responden yang telah memenuhi aspek variabel yang telah ditetapkan yaitu kependudukan, ketenagakerjaan, tingkat konsumsi, jaminan kesehatan, pendidikan serta tempat tinggal. Mereka yang sejahtera yaitu yang jumlah tanggungan dalam keluarganya sedikit serta jumlah orang yang memiliki penghasilan lebih dari 1 orang, dapat memenuhi kebutuhan serta keinginannya, memiliki hunian sendiri dan tidak menumpang ataupun menyewa, memiliki tabungan yang mencukupi, dana darurat untuk berjaga - jaga dan aset yang dapat digunakan sewaktu - waktu. Walaupun rata rata responden yang terkategori sejahtera mengalami peningkatan pengeluaran namun mereka masih bisa untuk memenuhi kebutuhan sehari - hari di masa pandemi ini serta masih memiliki dana darurat dan tabungan untuk berjaga - jaga sehingga faktor inilah yang menolong keluarga tersebut dari kondisi sulit. Beberapa responden menyatakan kesulitan mengikuti pembelajaran daring namun mereka tidak memiliki kendala sarana prasarana pendidikan di masa pandemi.

Sementara pada kondisi sebaliknya, keluarga yang termasuk dalam kategori tidak sejahtera yaitu sebanyak 30 responden adalah mereka yang tidak memiliki tabungan, dana darurat dan aset yang dapat digunakan sewaktu - waktu di keadaan sulit. Selebihnya, keluarga yang terkategori tidak sejahtera ini belum memiliki hunian sendiri serta mereka yang terkategori tidak sejahtera adalah yang juga tidak memiliki asuransi kesehatan untuk menjamin kesehatan keluarga. Selain itu, keluarga yang tergolong tidak sejahtera adalah keluarga yang hanya mampu memenuhi kebutuhan dasar, bahkan beberapa menyatakan bahwa pendapatan selama pandemi kurang mencukupi untuk memenuhi kebutuhan sehingga dari segi konsumsi terganggu. Dalam aspek pendidikan, kebanyakan responden menyatakan bahwa mereka kesulitan untuk mengikuti pembelajaran jarak jauh, beberapa menyatakan bahwa hal tersebut dipengaruhi karena terkendala oleh sarana prasarana pendidikan sehingga membuat pendidikan pun terganggu.

\section{Kesimpulan}

Berdasarkan hasil analisis penelitian dan pembahasan yang telah dijabarkan dalam bab IV maka dapat disimpulkan bahwa :

1. Kondisi dari indikator yang menjadi acuan seperti ketenagakerjaan, kependudukan, kepemilikan rumah, pendapatan, pendidikan dan kesehatan ada yang dikategorikan baik dan ada pula yang terkategori kurang baik karena adanya beberapa faktor yang tidak terpenuhi.

2. Kondisi kesejahteraan pelaku usaha mikro Kota Bandung berdasarkan metode range score BPS sudah masuk dalam kategori sejahtera karena berdasarkan hasil perhitungan berada pada angka 14,34 yang termasuk dalam rentang keluarga sejahtera. Namun perlu kajian lebih mendalam mengapa bida disimpulkan seperti ini karena hasil yang didapatkan tidak sesuai dengan fenomena yang ada.

\section{Daftar Pustaka}

[1] Abdillah. (2021, Juni 6). rumusrumus.com. Retrieved from rumusrumus.com website: https://rumusrumus.com/fenomenologi/

[2] Abdurrahim. (2020, Mei 23). sumaterapost. Retrieved from sumaterapost website: https://sumaterapost.co/dampak-kesejahteraan-keluarga-ditengah-pendemi-covid-19/

[3] Adiana, P. P., \& Karmini, N. L. (2014). Pengaruh Pendapatan, Jumlah Anggota Keluarga, dan Pendidikan Terhadap Pola Konsumsi Rumah Tangga Miskin di Kecamatan Gianyar. Jurnal Zoostek, 40.

[4] Alimoeso, S. (2020, Oktober 23). mediaindonesia.com. Retrieved from mediaindonesia.com: https://mediaindonesia.com/opini/355112/pandemi-covid-19-menguji-ketahanankeluarga 
[5] BPS. (2020). Perilaku Masyarakat di Masa Pandemi Covid - 19. Jakarta: BPS RI.

[6] CNNIndonesia. (2020, Desember 27). CNN Indonesia. Retrieved from CNN Indonesia Web Site: $\quad$ https://www.cnnindonesia.com/gaya-hidup/20201211074306-255-580771/10masalah-kesehatan-sepanjang-tahun-2020/6

[7] Firi. (2014, Maret 26). firiijb.wordpress.com. Retrieved from firiijb.wordpress.com website: https://firiijb.wordpress.com/2014/03/26/teori-ekonomi-kesejahteraan/

[8] Gilang, R. R. (2013). Pengaruh Pendapatan Terhadap Konsumsi Buruh Bangunan di Kecamatan Pineleng. Jurnal EMBA, 252.

[9] Harmadi, S. H. (2020, Juni 29). mediaindonesia. Retrieved from mediaindinesia website: https://mediaindonesia.com/opini/323946/ketahanan-keluarga-di-masa-pandemi

[10] Hendayana, Y. (2020, Oktober 28). Direktorat Jenderal Pendidikan Tinggi kementerian Pendidikan dan Kebudayaan Republik Indonesia. Retrieved from Direktorat Jenderal Pendidikan Tinggi kementerian Pendidikan dan Kebudayaan Republik Indonesia Web SIte: https://dikti.kemdikbud.go.id/kabar-dikti/kabar/tantangan-dunia-pendidikan-dimasa-pandemi/

[11] Herawati, D. T. (2020, Juni 29). ipb.ac.id. Retrieved from ipb.ac.id website: https://www.ipb.ac.id/news/index/2020/06/peran-keluarga-menjadi-kunci-utama-di-erapandemi-covid-19-dan-new-normal/97065bf36bb764b8257e2b474ab6102f

[12] IPB, D. (2020, Juni 19). DPIS IPB. Retrieved from DPIS IPB Website: https://dpis.ipb.ac.id/mencegah-krisis-keluarga-indonesia-di-saat-pandemi-covid-19/

[13] Iskandar, Hartoyo, Sumarwan, U., \& Khomsan, A. (2006). Faktor - Faktor Yang Memengaruhi Kesejahteraan Keluarga. Jurnal USU, 133 - 141.

[14] Jayani, D. H. (2020, Juni 25). Databoks. Retrieved from Databoks Web Site: https://databoks.katadata.co.id/datapublish/2020/06/26/survei-smrc-kondisi-ekonomikeluarga-lebih-buruk-setelah-pandemi-covid-19\#

[15] Kuncoro, M. (2009). Metode Riset Untuk Bisnis \& Ekonomi. Jakarta: Penerbit Erlangga.

[16] LIPI. (2020, Agustus 20). LIPI. Retrieved from LIPI Web Site: http://lipi.go.id/berita/surveiekonomi-rumah-tangga-indonesia-di-masa-pandemi-covid-19/22121

[17] Mufidayati, K. (2020, Juni 29). Kumparan. Retrieved from Kumparan Web Site: https://kumparan.com/media-mufida/tantangan-ketahanan-keluarga-di-masa-pandemicovid-19-1thonp3JGUF/full

[18] Muskananfola, I. A. (n.d.). Pengaruh Pendapatan, Konsumsi, dan Pemahaman Perencanaan Keuangan Terhadap Proporsi Tabungan Rumah Tangga Kelurahan Tenggilis. Jurnal Manajemen Keuangan, 62.

[19] Nurhayati, T., \& Aji, R. H. (2020). Emansipasi Melawan Pandemi Global; Bukti Dari Indonesia. ADALAH, Buletin Hukum \& Keadilan, 81-92.

[20] Nursyabani, F. (2021, Februari 25). Ayobandung.com. Retrieved from Ayobandung.com Website: https://ayobandung.com/read/2021/02/25/193182/angka-stunting-kotabandung-naik-2-39

[21] Poerwadarminto, W. (1999). Kamus Besar Bahasa Indonesia. In W. Poerwadarminto, Kamus Besar Bahasa Indonesia (p. 887). Jakarta: Balai Pustaka.

[22] Rachmawati, A. R. (2020, Agustus 16). Pikiran Rakyat. Retrieved from Pikiran Rakyat Website: https://www.pikiran-rakyat.com/bandung-raya/pr-01670731/600-umkm-dibandung-terdampak-selama-pandemi-covid-19

[23] Sekaran, U., \& Bougie, R. (2013). Research Methods For Business Edisi 4 Buku 2. Jakarta: Wiley.

[24] Septiyani, A. (2021, Januari 4). Ayobandung.com. Retrieved from Ayobandung.com Website: $\quad$ https://ayobandung.com/read/2021/01/04/171022/keberlangsunganpendidikan-di-kala-pandemi

[25] Shahreza, D., \& Lindiawatie. (2020). Ketahanan EKonomi Keluarga di Depok Pada MAsa PAndemi Covid - 19. Journal of Applied Business and Economics (JABE), 148-161. 
[26] Subandi, D. (2016). Ekonomi Pembangunan. In D. S. M.M, Ekonomi Pembangunan (p. 15). Bandung: Alfabeta.

[27] Sugiyono, P. D. (2008). Metode Penelitian Bisnis. In P. D. Sugiyono, Metode Penelitian Bisnis (pp. 132-133). Bandung: Alfabeta Bandung.

[28] Sugiyono, P. D. (2008). Metode Penelitian Bisnis. In P. D. Sugiyono, Metode Penelitian Bisnis (Pendekatan Kuantitatif, Kualitatif dan R\&D) (p. 14). Bandung: Penerbit Alfabeta.

[29] Sugiyono, P. D. (2008). Metode Penelitian Bisnis. In P. D. Sugiyono, Metode Penelitian Bisnis (Pendekatan Kuantitati, Kualitatif dan R\&D) (p. 392). Bandung: Penerbit Alfabeta.

[30] Supianto, Khosmas, F., \& Utomo, B. B. (2015). Pengaruh Pendapatan Keluarga Terhadap Pembiayaan Pendidikan Anak Pada Masyarakat Seputar Danau Sentarum. 1-10.

[31] Ubaidillah, A. (2020, April 17). detikHealth. Retrieved from detikHealth website: https://health.detik.com/berita-detikhealth/d-4980815/5-manfaat-miliki-asuransikesehatan-keluarga-saat-pandemi-covid-19

[32] Undang - Undang No. 10 Tahun 1992. (1992). Indonesia.

[33] Wahbi, A. A., Syahrudi, \& Ariwibowo, P. (2020). Pengaruh Pendapatan Terhadap Kesejahteraan Keluarga Pada Industri Konveksi di Kampung Bulak Timur Depok Jawa Barat. Jurnal Ilmu Manajemen dan Akuntansi Vol. 8, No.1, 52-60.

[34] Wakhidatul, S. N. (2020, November 19). Kompasiana.com. Retrieved from Kompasiana.com website: https://www.kompasiana.com/dewihidayati2287/5fb66cf9d541df470742ad74/manfaatk an-pandemi-dengan-small-bisnis 